\title{
Latifolosides I and J, Two New Triterpenoid Saponins from the Bark of Ilex latifolia
}

\author{
Jing Huang, ${ }^{a}$ Xu Wang, ${ }^{b}$ Yukio Ogihara, ${ }^{a}$ Noriko Shimizu, ${ }^{b}$ Tadahiro Takeda, ${ }^{*, b}$ and \\ Toshiyuki AKIYAMA ${ }^{c}$ \\ Faculty of Pharmaceutical Sciences, Nagoya City University, ${ }^{a}$ Tanabe-dori, Mizuho-ku, Nagoya 467-8603, Japan, Kyoritsu \\ College of Pharmacy, ${ }^{b}$ 1-5-30 Shibakoen, Minato-ku, Tokyo 105-8512, Japan, and Research Planning Department, \\ Sankyo Co. Ltd., ${ }^{c}$ 1-2-58 Hiromachi, Shinagawa-ku, Tokyo 140-8710, Japan. \\ Received August 14, 2000; accepted October 17, 2000
}

\begin{abstract}
Two new triterpenoid saponins, latifoloside I (1), 3- $O$ - $\alpha$-L-rhamnopyranosyl-(1 $\rightarrow 2)$ - $\beta$-D-glucopyranosyl $3 \beta, 21 \alpha, 28$-trihydroxy-urs-12-ene 21- $O$ - $\beta$-D-glucopyranoside; latifoloside $\mathrm{J}(2), 3-O$ - $\alpha$-L-rhamnopyranosyl-(1 $\rightarrow 2)$ $\beta$-D-glucopyranosyl-3 $\beta, 21 \alpha$-dihydroxy-ursolic acid $21-O$ - $\beta$-D-glucopyranoside, along with two known compounds, latifoloside $C$ (3) and latifoloside $E$ (4), were isolated from the bark of Ilex latifolia ThunB. Structure assignments were established on the basis of spectroscopic data and chemical evidence.
\end{abstract}

Key words Ilex latifolia; Aquifoliaceae; triterpenoid saponin; latifoloside I; latifoloside J

Ilex latifolia THUNB., one of the species in the Ilex genus used in the tea Ku-Ding-Cha, has been used in China as a diuretic, remedy for sore throats, weight loss and for a relief of hypertension. ${ }^{1)}$ From the leaves, Ouyang et al. ${ }^{2)}$ have isolated eight new triterpenoid saponins. In a previous paper, ${ }^{3)}$ we reported the identity of the triterpenes from the bark of this species. As a part of our continuing study, this paper deals with the isolation and structural elucidation of two new triterpenoid saponins, latifoloside I (1) and J (2), along with two known compounds, latifoloside C (3) and latifoloside E (4), from the bark of I. latifolia.

\section{Results and Discussion}

The bark of I. latifolia was extracted with methanol and the methanol extract was partitioned between water with $n$ hexane and $n$-butanol, respectively. Chromatography of the $n$-butanol extract on silica gel, Lobar RP-18, and Sephadex LH-20, and then after repeated HPLC purification over octadecyl silica (ODS) gel, furnished two new saponins $(\mathbf{1}, \mathbf{2})$, and two known ones $(\mathbf{3}, 4)$.

Latifoloside I (1) was obtained as a colorless powder, and had the molecular formula $\mathrm{C}_{48} \mathrm{H}_{80} \mathrm{O}_{17}$ based on the high resolution (HR)-FAB-MS spectrum. The ${ }^{13} \mathrm{C}-\mathrm{NMR}$ spectral data of 1 showed 48 carbon signals, 30 of which were assigned to the aglycone part, while 18 were assigned to the carbohydrate moiety. The seven methyl carbon signals at $\delta 16.0$, $17.0,17.2,17.8,17.8,23.0$, and 28.1, and two olefinic carbons at $\delta 125.1$ and 139.5, indicated that the aglycone of $\mathbf{1}$ had an uvaol-type skeleton. In comparing with the ${ }^{1} \mathrm{H}-,{ }^{13} \mathrm{C}$ NMR spectral data of $\mathbf{1}$ with those of uvaol, ${ }^{4)}$ they were very similar, except for a signal at $\delta 76.8(\mathrm{CH}$ by distortionless enhancement by polarization transfer, DEPT). From a heteronuclear multiple bond coherence spectroscopy (HMBC) experiment of $\mathbf{1}$, the long-range coupling of H-30 ( $\delta$ 1.27) with $\delta 76.8$ was observed. Therefore, there should be a hydroxyl group at $\mathrm{C}-21$. This assignment was confirmed by the downfield shifts of C-20 (+3.7 ppm), C-21 (+43.1 ppm), and $\mathrm{C}-22(+8.4 \mathrm{ppm})$, and the upfield shifts of C-30 $(-3.5 \mathrm{ppm})$. The signal at $\delta 88.8$ on the ${ }^{13} \mathrm{C}-\mathrm{NMR}$ spectrum of 1 revealed there should be a hydroxyl group at C-3. The relative configuration of the hydroxyl at C-3 could be deter- mined using the rotating frame Overhouser enhancement spectroscopy (ROESY) experiment. The correlations of $\mathrm{H}_{\mathrm{ax}}-$ $3(\delta 3.22$, dd, $J=11.3,4.0 \mathrm{~Hz})$ and $\mathrm{H}-5(\delta 0.71, \mathrm{dd}, J=11.3$, $4.6 \mathrm{~Hz}$ ) indicated that the hydroxyl at $\mathrm{C}-3$ should have a $\beta$ configuration. The relatively small coupling constants $(2.9 \mathrm{~Hz})$ of $\mathrm{H}-21(\delta 4.32)$ indicated that the hydroxyl at C-21 should have an $\alpha$-configuration. Based on these findings, the structure of the aglycone part of $\mathbf{1}$ was established to be $3 \beta, 21 \alpha, 28$-trihydroxy-urs-12-ene.

The ${ }^{1} \mathrm{H}$ - and ${ }^{13} \mathrm{C}-\mathrm{NMR}$ data of 1 showed three anomeric signals at $\delta 4.96(\mathrm{~d}, J=7.5 \mathrm{~Hz}), 5.08(\mathrm{~d}, J=7.6 \mathrm{~Hz})$, and 6.56 (brs), and $\delta 105.5,101.8$, and 101.6, respectively. Acid hydrolysis of 1 gave two monosaccharides: glucose and rhamnose $(2: 1)$, which were analyzed by GC as their alditol acetate derivatives. The absolute configurations of the sugars were shown to be D-glucose, and L-rhamnose according to the method reported by Hara and co-workers. ${ }^{5}$ NMR techniques, ${ }^{1} \mathrm{H}-{ }^{1} \mathrm{H}$ shift correlation spectroscopy (COSY), heteronuclear multiple quantum coherence spectroscopy (HMQC), HMBC, and ROESY, were used to determine the nature of the monosaccharides and sequences of the oligosaccharide chain of $\mathbf{1}$. The anomeric configurations and ring sizes of each sugar were obtained following analysis on the $\mathrm{H}-1$ vicinal coupling constants $\left({ }^{3} J_{\mathrm{HH}},{ }^{1} J_{\mathrm{CH}}\right)$, observing their $\mathrm{H}-1$ chemical shifts, and comparing their ${ }^{13} \mathrm{C}-\mathrm{NMR}$ spectral data with those of methyl glycosides. $\left.{ }^{6}\right)$ From the relatively large H-1 coupling constants $(7.5,7.6 \mathrm{~Hz})$, the anomeric configuration for both glucose moieties should be $\beta$. In the insensitive nuclei enhanced by polarization transfer (INEPT) spectrum, the $\mathrm{CH}$ coupling constant of the $\mathrm{C}-1(\delta$ 101.8) signal was $178 \mathrm{~Hz}$, indicating that the glycosidic bond of rhamnose was linked in an $\alpha$-configuration. Based on these results, the three sugars and their anomeric configurations in 1 were determined to be two $\beta$-D-glucopyranoses and an $\alpha$-L-rhamnopyranose.

The sequence of the oligosaccharide chain was deduced from ${ }^{13} \mathrm{C}$ shift differences between individual sugar residues and model compounds, and from HMBC and ROESY experiments. The $\mathrm{C}-1$ of a glucose was attached to the $3-\mathrm{OH}$ of the aglycone, as indicated by the C-3 chemical shift $(\delta 88.8)$ of 1 as well as by the correlations of H-1 ( $\delta 4.96)$ of an inner glu- 


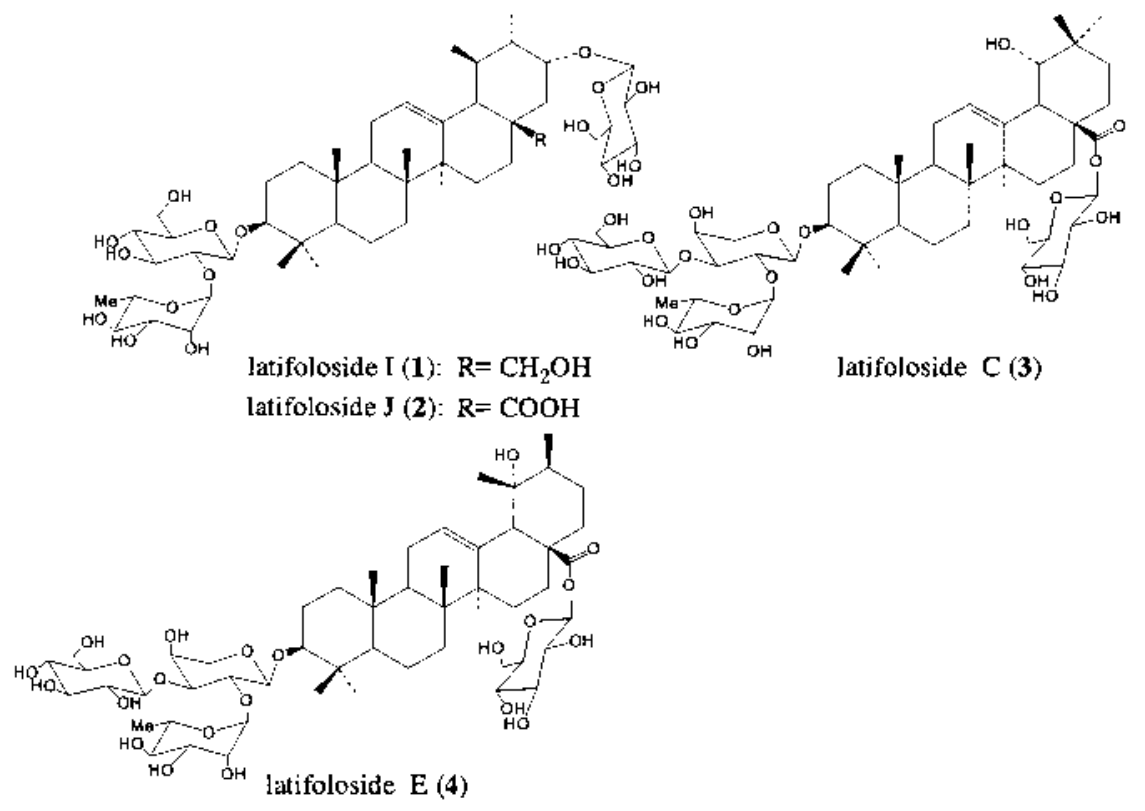

Chart 1

cose and $\mathrm{C}-3$ of the aglycone in $\mathrm{HMBC}$, and $\mathrm{H}-1$ of the inner glucose and $\mathrm{H}-3$ ( $\delta 3.22)$ of the aglycone in ROESY. From the HMBC experiment of $\mathbf{1}$, the following correlations were observed: $\mathrm{H}-1(\delta 5.08)$ of the terminal glucose and C-21 $(\delta$ $76.8)$ of the aglycone; $\mathrm{H}-1(\delta 6.56)$ of a rhamnose and $\mathrm{C}-2(\delta$ 77.9) of the inner glucose. Based on the above findings, the structure of 1 was elucidated to be 3-O- $\alpha$-L-rhamnopyranosyl-( $(1 \rightarrow 2)-\beta$-D-glucopyranosyl $3 \beta, 21 \alpha, 28$-trihydroxy-urs12 -ene $21-O-\beta$-D-glucopyranoside. This is a new triterpenoid saponin, trivially named latifoloside I.

Latifoloside J (2) was also obtained as a colorless powder, and had a molecular formula $\mathrm{C}_{48} \mathrm{H}_{78} \mathrm{O}_{18}$ based on its HRFAB-MS spectrum. The ${ }^{13} \mathrm{C}-\mathrm{NMR}$ spectral data of 2 showed 48 carbon signals, 30 of which were assigned to the aglycone part, while 18 were assigned to the carbohydrate moiety. The seven methyl carbon signals at $\delta 15.8,17.2,17.5,17.6,17.8$, 23.3, and 28.1, and three $s p^{2}$ carbons at $\delta 125.2$ and 139.6, and 180.6 indicated that the aglycone of $\mathbf{2}$ had an ursolic acid skeleton. In comparing with the ${ }^{1} \mathrm{H}-,{ }^{13} \mathrm{C}-\mathrm{NMR}$ spectra data of 2 with those of literature, ${ }^{5)}$ the aglycone part of $\mathbf{2}$ was identified as $3 \beta, 21 \alpha$-dihydroxy-urs-12-en-28-oic acid.

The ${ }^{1} \mathrm{H}$ - and ${ }^{13} \mathrm{C}-\mathrm{NMR}$ data of $\mathbf{2}$ displayed three anomeric signals at $\delta 4.94(\mathrm{~d}, J=7.3 \mathrm{~Hz}), 5.01(\mathrm{~d}, J=7.6 \mathrm{~Hz})$, and 6.55 (brs), and $\delta 105.4,101.7$, and 101.6, respectively. Acid hydrolysis gave two monosaccharides, glucose and rhamnose in a ratio of $2: 1$, which were analyzed using the same method as the identification in $\mathbf{1}$. Using the same methods in $\mathbf{1}$, glucose was determined to have a D-configuration, while rhamnose was determined to have an L-configuration. The sequence of the oligosaccharide chain was deduced from ${ }^{13} \mathrm{C}$ shift differences between individual sugar residues and model compounds, and from HMBC and ROESY experiments. The $\mathrm{C}-1$ of an inner glucose was attached to the $3-\mathrm{OH}$ of the aglycone, as indicated by the $\mathrm{C}-3$ chemical shift $(\delta$ $88.9)$ of 2 , and the correlations of H-1 $(\delta 4.93)$ of the inner glucose and $\mathrm{C}-3$ of the aglycone in HMBC, as well as of $\mathrm{H}-1$ of the inner glucose with $\mathrm{H}-3(\delta 3.37, \mathrm{dd}, J=11.2,4.6 \mathrm{~Hz})$ in ROESY. The rhamnose attached to $\mathrm{C}-2$ of the inner glucose was determinated by the correlation between $\mathrm{H}-1(\delta 6.55)$ of rhamnose and $\mathrm{C}-2(\delta$ 77.8) of the inner glucose in HMBC experiment of 2 . The other glucose attached to $21-\mathrm{OH}$ of the aglycone had a correlation between H-1 $(\delta 5.01)$ of glucose and $\mathrm{C}-21(\delta 76.9)$ of the aglycone; and the down-field shift $(+5.1 \mathrm{ppm})$ of $\mathrm{C}-21$ in 2 was different from the literature. ${ }^{6}$ Based on the above findings, the structure of 2 was elucidated to be 3-O- $\alpha$-L-rhamnopyranosyl-( $1 \rightarrow 2)$ - $\beta$-D-glucopyranosyl $3 \beta, 21 \alpha$-dihydroxy-urs-12-en-28-oic acid 21-O- $\beta$-Dglucopyranoside. This is a new triterpenoid saponin, trivially named latifoloside $\mathrm{J}$.

Latifolosides C (3) and E (4) were obtained as colorless powders. Their molecular peaks were both at $\mathrm{m} / z 1074[\mathrm{M}]^{-}$ in FAB-MS. Comparing the ${ }^{1} \mathrm{H}-,{ }^{13} \mathrm{C}-\mathrm{NMR}$ data of 3 and 4 with those of literature, $\left.{ }^{2 a}\right) \mathbf{3}$ and $\mathbf{4}$ were identified as $3-O-\beta$-Dglucopyranosyl- $(1 \rightarrow 3)$-[ $\alpha$-L-rhamnopyranosyl- $(1 \rightarrow 2)-]-\alpha$-Larabinopyranosyl siaresinolic acid $28-O-\beta$-D-glucopyranoside and 3-O- $\beta$-D-glucopyranosyl-( $(1 \rightarrow 3)$ - $[\alpha$-L-rhamnopyranosyl$(1 \rightarrow 2)$-]- $\alpha$-L-arabinopyranosyl ilexgenin B $28-O-\beta$-D-glucopyranoside, respectively.

\section{Experimental}

General Optical rotations were measured using a DIP-140 digital polarimeter (JASCO corporation). HR-FAB-MS was conducted using a JMSSX102A (JEOL) mass spectrometer. ${ }^{1} \mathrm{H}$ - and ${ }^{13} \mathrm{C}-\mathrm{NMR}$ were recorded using a JEOL FT-NMR JNM A-500 and/or a Lambda 500 FT-NMR spectrometer $\left({ }^{1} \mathrm{H}\right.$ at $500 \mathrm{MHz},{ }^{13} \mathrm{C}$ at $\left.125 \mathrm{MHz}\right)$. Standard pulse sequences were used for the two dimensions (2D)-NMR experiments. Chemical shifts were expressed in $\delta(\mathrm{ppm})$ downfield from tetramethylsilane (TMS) as an internal standard and coupling constants $(J)$ were reported in Hertz $(\mathrm{Hz})$. TLC was carried out on Silica gel $60 \mathrm{~F}_{254}$, and the spots were visualized by spraying with $10 \%$ $\mathrm{H}_{2} \mathrm{SO}_{4}$ and heating. Silica gel (silica gel 60-70, 230 mesh, Merck), Lichroprep RP-18 (Lobar, 40 - $63 \mu \mathrm{m}$, Merck) and Sephadex LH-20 were used for column chromatography. Preparative HPLC was performed using an ODS column (PEGASIL ODS, $250 \times 10 \mathrm{~mm}$, Senshu Pak; detector: refractive index and UV $210 \mathrm{~nm}$ ).

Isolation of Saponins The bark of Ilex latifolia ThNuB. was obtained in Tokyo, Japan in 1998. The voucher specimens were identified by Dr. Toshiyuki Akiyama and deposited in Research Planning Department, Sankyo Co. Ltd. Dried powder $(2 \mathrm{~kg})$ of the bark of I. latifolia was extracted with $\mathrm{MeOH}(121 \times 2)$ under reflux conditions. The $\mathrm{MeOH}$ extract $(21)$ was partitioned successively between water with $n$-hexane and $n$-butanol, respec- 
Table $1 .{ }^{13} \mathrm{C}-\mathrm{NMR}$ Spectral Data of Latifolosides I and J (1, 2) $(125 \mathrm{MHz}$ in Pyridine- $d_{5}$ )

\begin{tabular}{|c|c|c|c|c|c|c|c|}
\hline Carbons & I (1) & $\mathrm{J}(2)$ & DEPT & Sugars & $\mathrm{I}(\mathbf{1})$ & $\mathrm{J}(\mathbf{2})$ & DEPT \\
\hline $\mathrm{C}-1$ & 39.4 & 39.3 & $\mathrm{CH}_{2}$ & 3-O-Glucose & & & \\
\hline C-2 & 26.9 & 26.9 & $\mathrm{CH}_{2}$ & G-1 & 105.5 & 105.4 & $\mathrm{CH}$ \\
\hline C-3 & 88.8 & 88.9 & $\mathrm{CH}^{2}$ & $\mathrm{G}-2$ & 77.9 & 77.8 & $\mathrm{CH}$ \\
\hline C-4 & 39.5 & 39.5 & $\mathrm{C}$ & G-3 & 78.2 & 78.2 & $\mathrm{CH}$ \\
\hline C-5 & 56.0 & 56.2 & $\mathrm{CH}$ & G-4 & 72.2 & 72.1 & $\mathrm{CH}$ \\
\hline C-6 & 18.5 & 18.5 & $\mathrm{CH}_{2}$ & G-5 & 78.3 & 78.3 & $\mathrm{CH}$ \\
\hline C-7 & 33.3 & 33.6 & $\mathrm{CH}_{2}$ & G-6 & 63.2 & 63.2 & $\mathrm{CH}_{2}$ \\
\hline C-8 & 42.6 & 42.9 & C & Rhamnose & & & \\
\hline C-9 & 48.0 & 48.0 & $\mathrm{CH}$ & R-1 & 101.6 & 101.6 & $\mathrm{CH}$ \\
\hline C-10 & 36.8 & 36.9 & $\mathrm{C}$ & R-2 & 72.5 & 72.4 & $\mathrm{CH}$ \\
\hline C-11 & 23.6 & 23.6 & $\mathrm{CH}_{2}$ & $\mathrm{R}-3$ & 72.6 & 72.5 & $\mathrm{CH}$ \\
\hline C-12 & 125.1 & 125.2 & $\mathrm{CH}$ & R-4 & 74.2 & 74.1 & $\mathrm{CH}$ \\
\hline C-13 & 139.5 & 139.6 & C & R-5 & 69.6 & 69.6 & $\mathrm{CH}$ \\
\hline C-14 & 40.1 & 39.8 & C & R-6 & 18.5 & 18.5 & $\mathrm{CH}_{3}$ \\
\hline C-15 & 26.6 & 29.2 & $\mathrm{CH}_{2}$ & 21-O-Glucose & & & \\
\hline C-16 & 26.5 & 27.7 & $\mathrm{CH}_{2}$ & G-1 & 101.8 & 101.7 & $\mathrm{CH}$ \\
\hline C-17 & 37.3 & 48.5 & $\mathrm{C}$ & G-2 & 75.5 & 75.4 & $\mathrm{CH}$ \\
\hline C-18 & 54.8 & 54.3 & $\mathrm{CH}$ & G-3 & 79.0 & 78.9 & $\mathrm{CH}$ \\
\hline C-19 & 33.7 & 33.6 & $\mathrm{CH}$ & G-4 & 72.3 & 72.2 & $\mathrm{CH}$ \\
\hline C-20 & 43.1 & 42.9 & $\mathrm{CH}$ & G-5 & 79.9 & 79.8 & $\mathrm{CH}$ \\
\hline C-21 & 76.8 & 76.9 & $\mathrm{CH}$ & G-6 & 63.0 & 62.9 & $\mathrm{CH}_{2}$ \\
\hline $\mathrm{C}-22$ & 39.0 & 39.1 & $\mathrm{CH}_{2}$ & & & & \\
\hline C-23 & 28.1 & 28.1 & $\mathrm{CH}_{3}$ & & & & \\
\hline C-24 & 17.2 & 17.2 & $\mathrm{CH}_{3}$ & & & & \\
\hline C-25 & 16.0 & 15.8 & $\mathrm{CH}_{3}$ & & & & \\
\hline C-26 & 17.0 & 17.6 & $\mathrm{CH}_{3}$ & & & & \\
\hline $\mathrm{C}-27$ & 23.0 & 23.3 & $\mathrm{CH}_{3}$ & & & & \\
\hline C-28 & 68.8 & 180.6 & $\mathrm{CH}_{2}(\mathrm{C})$ & & & & \\
\hline C-29 & 17.8 & 17.5 & $\mathrm{CH}_{3}$ & & & & \\
\hline C-30 & 17.8 & 17.8 & $\mathrm{CH}_{3}$ & & & & \\
\hline
\end{tabular}

tively. After removing the solvent, the $n$-butanol extract $(58 \mathrm{~g}$ ) was dissolved in methanol $(350 \mathrm{ml})$ and the methanol solution was dropped into ether $(61)$ to get a precipitate $(40 \mathrm{~g})$ and ether-soluble part $(8 \mathrm{~g})$. Thirty grams of the ether precipitate was chromatographed on a silica gel column with a solvent system of $\mathrm{CHCl}_{3}-\mathrm{MeOH}-\mathrm{H}_{2} \mathrm{O}(10: 2: 0.2 ; 7: 2: 0.2)$ to get six fractions according to their TLC behavior. Fraction $6(13 \mathrm{~g})$ was chromatographed on a silica gel column with a solvent system of $\mathrm{CHCl}_{3}-\mathrm{MeOH}-\mathrm{H}_{2} \mathrm{O}(8: 2: 0.2$; $8: 4: 0.2 ; 7: 4: 1)$ to get parts $1-7$. Part $6(830 \mathrm{mg})$ was chromatographed on a Lobar RP-8 column (solvent: $\mathrm{CH}_{3} \mathrm{OH}: \mathrm{H}_{2} \mathrm{O}=5: 5$ ) to get p6-1-3. P6-1 $\left(400 \mathrm{mg}\right.$ ) was chromatographed on a Lobar RP-18 column with $\mathrm{CH}_{3} \mathrm{CN}$ : $\mathrm{H}_{2} \mathrm{O}(3: 7)$ as an eluent to get latifoloside I (1, $\left.24 \mathrm{mg}\right)$. P6-2 (360 mg) was chromatographed on a silica gel column with a solvent system of $\mathrm{CHCl}_{3}-$ $\mathrm{MeOH}-\mathrm{H}_{2} \mathrm{O}(8: 2: 0.2)$, to get p6-2-1-2. P6-2-1 (190 mg) was further purified on a Lobar RP-18 column with $\mathrm{CH}_{3} \mathrm{CN}: \mathrm{H}_{2} \mathrm{O}(3: 7)$ as an eluent to get latifoloside $\mathrm{J}(2,14.2 \mathrm{mg})$. P6-2-2 (150 mg) was isolated on HPLC with $\mathrm{CH}_{3} \mathrm{OH}: \mathrm{H}_{2} \mathrm{O}(5: 5)$ as an eluent to get latifoloside $\mathrm{C}(\mathbf{3}, 6.8 \mathrm{mg})$ and latifoloside $\mathrm{E}(\mathbf{4}, 6.8 \mathrm{mg})$.
Latifoloside I (1): $[\alpha]_{\mathrm{D}}^{25}:+36.7^{\circ}(c=0.21, \mathrm{MeOH})$; HR-FAB-MS (negative): $m / z$ : $927.5375[\mathrm{M}-1]^{-}$(Calcd for $\mathrm{C}_{48} \mathrm{H}_{79} \mathrm{O}_{17} ; 927.5317$ ). ${ }^{1} \mathrm{H}-\mathrm{NMR}$ $\left(500 \mathrm{MHz}\right.$, pyridine- $\left.d_{5}\right): \delta(\mathrm{ppm}) 0.71(1 \mathrm{H}, \mathrm{dd}, J=11.3,4.6 \mathrm{~Hz}, \mathrm{H}-5), 0.86$ $(3 \mathrm{H}, \mathrm{s}, \mathrm{H}-25), 0.94(3 \mathrm{H}, \mathrm{s}, \mathrm{H}-26), 0.96(3 \mathrm{H}, \mathrm{d}, J=6.7 \mathrm{~Hz}, \mathrm{H}-29), 1.12(3 \mathrm{H}, \mathrm{s}$, H-27), 1.19 (3H, s, H-24), 1.23 (3H, s, H-23), 1.27 (3H, d, $J=6.4 \mathrm{~Hz}, \mathrm{H}-30)$, $1.72(3 \mathrm{H}, \mathrm{d}, J=6.1 \mathrm{~Hz}, \mathrm{H}-6$ of rhamnose), $2.54(1 \mathrm{H}, \mathrm{d}, J=11.6 \mathrm{~Hz}, \mathrm{H}-18)$, $3.22(1 \mathrm{H}, \mathrm{dd}, J=11.3,4.0 \mathrm{~Hz}, \mathrm{H}-3), 3.58(1 \mathrm{H}, \mathrm{d}, J=10.4 \mathrm{~Hz}, \mathrm{H}-28 \mathrm{a}), 3.88$ $(1 \mathrm{H}, \mathrm{d}, J=10.4 \mathrm{~Hz}, \mathrm{H}-28 \mathrm{~b}), 4.32(1 \mathrm{H}, \mathrm{m}, \mathrm{H}-21), 4.96(1 \mathrm{H}, \mathrm{d}, J=7.5 \mathrm{~Hz}, \mathrm{H}-1$ of inner glucose), $5.08(1 \mathrm{H}, \mathrm{d}, J=7.6 \mathrm{~Hz}, \mathrm{H}-1$ of terminal glucose), 6.56 (1H, br s, $\mathrm{H}-1$ of rhamnose). ${ }^{13} \mathrm{C}-\mathrm{NMR}$ spectral data are given in Table 1.

Latifoloside J (2): $[\alpha]_{\mathrm{D}}^{25}:+7.4^{\circ}(c=0.67, \mathrm{MeOH})$; HR-FAB-MS (negative): $m / z$ : $941.5110[\mathrm{M}-1]^{-}$(Calcd for $\mathrm{C}_{48} \mathrm{H}_{77} \mathrm{O}_{18} ;$ 941.5037). ${ }^{1} \mathrm{H}-\mathrm{NMR}$ $\left(500 \mathrm{MHz}\right.$, pyridine- $\left.d_{5}\right): \delta(\mathrm{ppm}) 0.71(1 \mathrm{H}, \mathrm{dd}, J=11.6,4.4 \mathrm{~Hz}, \mathrm{H}-5), 0.83$ $(3 \mathrm{H}, \mathrm{s}, \mathrm{H}-25), 1.01(3 \mathrm{H}, \mathrm{d}, J=6.7 \mathrm{~Hz}, \mathrm{H}-29), 1.02(3 \mathrm{H}, \mathrm{s}, \mathrm{H}-26), 1.11$ (3H, s, H-27), 1.17 (3H, s, H-24), 1.22 (3H, s, H-23), $1.26(3 \mathrm{H}, \mathrm{d}, J=6.4 \mathrm{~Hz}, \mathrm{H}-30)$, $1.70(3 \mathrm{H}, \mathrm{d}, J=6.4 \mathrm{~Hz}, \mathrm{H}-6$ of rhamnose), $2.78(1 \mathrm{H}, \mathrm{d}, J=11.3 \mathrm{~Hz}, \mathrm{H}-18)$, $3.37(1 \mathrm{H}, \mathrm{dd}, J=11.2,4.6 \mathrm{~Hz}, \mathrm{H}-3), 4.28(1 \mathrm{H}, \mathrm{m}, \mathrm{H}-21), 4.94(1 \mathrm{H}, \mathrm{d}$, $J=7.3 \mathrm{~Hz}, \mathrm{H}-1$ of inner glucose $), 5.01(1 \mathrm{H}, \mathrm{d}, J=7.6 \mathrm{~Hz}, \mathrm{H}-1$ of terminal glucose), 6.55 (1H, br s, $\mathrm{H}-1$ of rhamnose). ${ }^{13} \mathrm{C}$-NMR spectral data are given in Table 1.

Latifoloside C (3): $[\alpha]_{\mathrm{D}}^{25}:+10.2^{\circ}(c=0.69, \mathrm{MeOH})$; FAB-MS: $m / z: 1074$ $[\mathrm{M}]^{-}$.

Latifoloside E (4): $[\alpha]_{\mathrm{D}}^{25}:+16.4^{\circ}(c=0.65, \mathrm{MeOH})$; FAB-MS: $m / z: 1074$ $[\mathrm{M}]^{-}$

Compounds 1 and 2 ( $1 \mathrm{mg}$ each) were hydrolyzed and acetylated. The glucitol and rhamnitol acetates from compounds $\mathbf{1}$ and $\mathbf{2}$ were detected by GC analysis in a ratio of $2: 1$. (Condition: Supelco SP-2380 fused silica capillary column; $0.53 \mathrm{~mm}$ i.d. $\times 15 \mathrm{~m}, 0.2 \mu \mathrm{m}$ film; column temperature: $140^{\circ} \mathrm{C} \rightarrow 220^{\circ} \mathrm{C}, 4^{\circ} \mathrm{C} / \mathrm{min}$; injection temperature: $250^{\circ} \mathrm{C}$.)

The absolute configurations of the sugars were determined according to the method reported by Hara and co-workers ${ }^{5}$ using GC. GC conditions: column: $3 \%$ ECNSS-M $(2 \mathrm{~m} \times 0.3 \mathrm{~mm})$ (Alltech Assos, Inc.); column temp.: $190^{\circ} \mathrm{C}$; injection temp.: $210^{\circ} \mathrm{C}$; retention times (min): L-rhamnose (8.6), Dglucose (49.2).

Acknowledgements We are grateful to Mrs. J. Hada, Dr. A. Nagatsu, Miss S. Kato, Miss T. Nakano, Miss. K. Iwasawa, Miss. T. Naito and Miss. H. Suzuki for providing NMR and MS data, respectively.

\section{Referrences}

1) a) Ahai R. K., "Iconographia Cormophytorum Sinicoru," Beijing Science, 1985, p. 641; b) Jiang Su Medical College, "Chinese Medicine Dictionary," Shanghai People Publishig House, Shanghai, 1975, p. 1288.

2) a) Ouyang M. A., Wang H. Q., Liu Y. Q., Yang C. R., Phytochemistry, 45, 1501-1504 (1997); b) Ouyang M. A., Liu Y. Q., Wang H. Q., Yang C. R., ibid., 49, 2483-2486 (1998).

3) Huang J., Ogihara Y., Shimizu R., Takeda T., Akiyama Y., Natural Medicines, 54, 107 (2000).

4) Mahato S. B., Kundu A. P., Phytochemistry, 37, 1517-1575 (1994).

5) Hara S., Okabe H., Mihashi K., Chem. Pharm. Bull., 35, 501-506 (1987).

6) Agrawal P. K., Phytochemistry, 31, 3307-3330 (1992). 